\title{
Can social capital be intentionally generated? \\ A randomized trial from rural South Africa
}

\author{
Paul M. Pronyk ${ }^{*}$ FRCP(C) PhD \\ Trudy Harpham ${ }^{+}$PhD \\ Joanna Busza ${ }^{\circ} \mathrm{MSc}$ \\ Godfrey Phetla* MA \\ Linda A. Morison ${ }^{\circ} \mathrm{MSc}$ \\ James R. Hargreaves ${ }^{\circ} \mathrm{PhD}$ \\ Julia C. Kim ${ }^{\star \circ} \mathrm{FRCP}(\mathrm{C}) \mathrm{MSc}$ \\ Charlotte $\mathrm{H}$. Watts ${ }^{\circ} \mathrm{PhD}$ \\ John DH Porter ${ }^{\circ}$ MD FRCP
}

* Rural AIDS \& Development Action Research Programme

School of Public Health, University of the Witwatersrand

- London School of Hygiene and Tropical Medicine

+ London South Bank University

Corresponding author: Paul Pronyk

School of Public Health

University of the Witwatersrand

PO Box 2 Acornhoek, South Africa 1360

Tele: +27137955076

Fax: +27 137955082

pronyk@agincourt.co.za

Total word count: 7,708

Key words: South Africa, microfinance, health, social capital, randomized trial

\section{Acknowledgements}

The study has received financial support from AngloAmerican Chairman's Fund Educational Trust, AngloPlatinum, Department for International Development (UK), The Ford Foundation, The Henry J. Kaiser Family Foundation, HIVOS, South African Department of Health and Welfare, and the Swedish International Development Agency. We would like to thank the Managing Director of SEF, John de Wit, and the many staff who have made this work possible. 


\begin{abstract}
With nearly two decades of descriptive research documenting positive associations between social capital and a number of economic, social and health outcomes, there have been few intervention studies that attempt to assess whether social capital can be intentionally generated. We conducted an intervention combining group based microfinance with a participatory gender and HIV training curriculum in rural South Africa. A cluster randomized trial among eight villages was used to assess intervention effects on social capital among 860 participants and matched comparison households. This was supported by a diverse portfolio of qualitative research.
\end{abstract}

After two years, we found large intervention effects on structural social capital, alongside shifts in most aspects of cognitive social capital - particularly solidarity and collective action. Qualitative research highlighted the ways in which economic and social gains enhanced participation in social groups, and the positive and negative effects of social support within loan groups and centres. There were numerous instances where individuals and loan centres worked to engage priority concerns in their communities both working through existing social networks, alongside establishing effective partnerships with village leadership structures, the police, the health sector and local NGOs. This is among the first experimental trials to suggest that social capital can be exogenously strengthened. The implications for community interventions in public health are further explored. 


\title{
Can social capital be intentionally generated?
}

\section{A randomized trial from rural South Africa}

\author{
Ubuntu - 'I am because you are’ (South Africa)
}

The concept of social capital first emerged in 1916 when Hanifan highlighted the importance of community involvement in a successful schooling system (Hanifan, 1916). More recently, Putnam's re-introduction of the term into public and academic debate has stimulated an explosion of research on social capital and its effects (Kawachi \& Berkman, 2000; Putnam et al., 1993). Social capital broadly refers to the system of norms, networks and trust relationships that enable communities to address common concerns (Coleman, 1988; Putnam et al., 1993; Woolcock \& Narayan, 2000). Research has demonstrated the benefits of social capital in a wide variety of fields including its potential to enhance income attainment (Maluccio et al., 2001; Narayan \& Pritchett, 1997), economic development (Knack \& Keefer, 1997; Wickrama \& Mulford, 1996; Woolcock \& Narayan, 2000), child development (Hagan et al., 1995), education (Coleman, 1988), and good governance (Evans, 1997).

There is also a growing literature linking social capital to better health - from longitudinal studies documenting associations with lower mortality rates (Berkman \& Syme, 1979; Kawachi et al., 1997), improvements in child health (Drukker et al., 2005), mental health (De Silva et al., 2004; Veenstra, 2000, 2002), and higher levels of self reported health (Miller et al., 2006). Greater stocks of social capital have also been associated with lower levels of sexually-transmitted infections (Holtgrave \& Crosby, 2003), alcohol abuse (Weitzman \& Chen, 2005), smoking (Lundborg, 2005), and rates of crime and violence 
(Galea et al., 2002). Detailed reviews of this literature are well-presented elsewhere (Bolin et al., 2003; Field, 2003; Macinko \& Starfield, 2001; Szreter \& Woolcock, 2004) .

Despite the strength of this work, it is increasingly recognized that research on social capital and health is poised at a critical juncture (De Silva et al., 2004; Macinko \& Starfield, 2001). Most of the studies above have been purely descriptive, identifying different patterns of associations between communities and countries. Observations from these "natural experiments" provide important insights into how societies function. However, research has often been limited by imperfect measurement tools and study designs, and statements about causal pathways have been difficult to make. Assessments often fail to distinguish between the structural dimensions of social capital such as membership in community organizations, and its cognitive components such as trust and solidarity. Studies have rarely employed complementary qualitative research to add depth to statistical observations, and most have focused on industrialized country settings.

Furthermore, understanding the relationship between social capital and health increasingly requires the application of lessons learned from previous descriptive studies to the design and implementation of community- level interventions (Hawe \& Shiell, 2000). Indeed, a natural extension of existing research is to ask whether and in what settings interventions can strengthen social capital, and whether this results in better health (Harpham et al., 2002; Kawachi \& Berkman, 2000; Thomson et al., 2004). Better understanding how to work effectively with communities around public health concerns has the potential to strengthen the relevance and application of social capital to policy and programme development. 
We recently conducted a cluster randomized trial exploring the effects of a combined microfinance and training intervention on levels of HIV and intimate partner violence (IPV) in rural South Africa (Pronyk et al., 2006). Over a two year period, levels of physical and sexual violence experienced by program participants were reduced by half. One explicit aim of the intervention was to generate changes in social capital - through stimulating participation in social networks, enhancing solidarity, and mobilizing communities around priority concerns including gender and HIV. Social capital was felt to be important both as a secondary outcome, as well as being a pathway variable with the potential to mediate intervention effects (RADAR, 2002a). In this paper, we draw upon quantitative and qualitative data from the IMAGE Study to explore whether, in a rural South African setting, social capital could be intentionally generated.

\section{Methods}

\section{Setting}

This study was set among eight villages in South Africa's rural Limpopo Province. The area is densely settled and adjacent to a platinum mining belt. Study villages were between two and $20 \mathrm{~km}$ from a main trading centre. Poverty remains widespread (Rose \& Charlton, 2003) with high levels of circular labour migration (Collinson et al., 2005). Few households have land or livestock sufficient to support livelihoods and the major source of income is government grants including pensions and child-support.

\section{The IMAGE intervention}

The Intervention with Microfinance for AIDS and Gender Equity (IMAGE) combined a microfinance program (Small Enterprise Foundation, SEF, Tzaneen, South Africa) with a gender and HIV training curriculum, and was implemented between 2001 and 2004 in 
communities with no prior access to microfinance services. Key components of the intervention are described elsewhere (RADAR, 2002b). Briefly, the poorest households were offered access to credit through group-based microfinance services for incomegenerating activities. Businesses were run by individual women, with loan groups of five guaranteeing each others' loans and repaying together to receive additional credit (Yunus, 1999). Approximately 40 women (eight groups of five) comprised one loan centre which met fortnightly to repay loans and discuss their businesses.

Based upon participatory learning and action principles (Freire, 1994), a 12 month training curriculum called 'Sisters-for-Life' (SFL) was implemented during fortnightly loan centre meetings. The programme included two phases: Phase One consisted of ten one-hour training sessions covering topics such as gender roles, cultural beliefs, relationships, communication, IPV and HIV. Training sessions aimed to strengthen communication skills, critical thinking and leadership. Since group-based learning can foster solidarity and collective action (Friedman \& O'Reilly, 1997), Phase Two encouraged wider community mobilization to engage both youth and men in the intervention communities. Key women were selected by each centre for further leadership training, and subsequently worked with their centres to mobilize around priority issues including HIV and IPV.

\section{Quantitative evaluation}

A cluster randomized trial was used to assess intervention effects among IMAGE participants and a matched comparison group across the eight study villages. A full description of the methods and study profile has been presented elsewhere (Pronyk et al., 2006). 
The number of villages included in the study was determined by the operational feasibility of delivering the intervention over a wide geographic area; time required for cohort recruitment and follow up; the need to enroll all eligible households in a village before expanding; and, ethical concerns about withholding participation from comparison villages for an extended period.

In this study, social capital was measured through surveys of IMAGE participants and randomly selected women matched by age and socio-economic status from comparison villages. Quantitative data were collected using face-to-face interviews by female interviewers, who had received four-weeks of intensive training, including technical, ethical, and safety considerations. As 12 months was required for full cohort enrolment, there was a two-year follow-up period for quantitative outcomes.

\section{Measuring social capital}

To measure social capital, we adopted a structural/cognitive distinction. Structural social capital (SSC) was measured by nature and intensity of participation in community organizations, while cognitive social capital (CSC) was measured by examining levels of reciprocity, solidarity and collective action (Table 1). As we were examining the effects of an intervention on social capital, we chose to conceptualize it as an individual attribute, rather than a collective property.

Measurement instruments were based on the World Bank's Social Capital Assessment Tool and related literature for assessing social capital in developing countries (Grootaert et al., 2003; Harpham et al., 2002; Krishna \& Shrader, 1999). Interview questions were 
piloted over a 3-month period to ensure local relevance of indicators and that questions and response codes were well understood by both interviewers and respondents.

\section{Statistical methods}

Socio-demographic characteristics of study households and the profile of social networks are presented as proportions at baseline. For the longitudinal assessment of intervention effects on social capital, crude measures of effect with 95\% confidence intervals were calculated, comparing the intervention group to the comparison group (prevalence or risk ratios, identified as RR). Binary indicators were generated for each CSC theme as outlined in table 1 . SSC was made binary based on proportions above and below the median value. A cluster-level analysis was performed by entering the log of village level summaries into an analysis of variance model including terms for the intervention and village pair.

Adjusted measures of effect (aRR) were calculated by generating standardised village level summaries. These were calculated as the ratio of observed to expected outcomes predicted by fitting a logistic regression model on individual data with binary outcomes as dependent variables (Grosskurth et al., 1995). Adjusted risk ratios were generated for all outcome data at follow-up, accounting for baseline differences, marital status and village-level clustering.

\section{Qualitative evaluation}

Qualitative data were collected by two anthropologists and a research assistant over a three year observation period. A variety of different methods were employed, including: 
non-participant observation of loan centre meetings ( $n=4$ centres); focus group discussions (FGD) with loan groups purposively selected by age (young, old, mixed) and success of microfinance involvement (good and poor performers) ( $\mathrm{n}=8$ groups followed over 2-3 loan disbursement rounds); key informant (KI) interviews (8 women followed over 3 years); interviews with program drop-outs $(n=8)$; and Participatory Learning and Action (PLA) exercises with young people in the wider community (8 groups over multiple sessions). In addition, training facilitators kept diaries for each loan centre $(n=12)$ describing the specific challenges associated with the training, the response of centre participants, and actions undertaken individually and collectively around priority issues.

All qualitative data was translated, transcribed and thematically coded in Nud*ist database (Qualitative Solutions \& Research v.6). A thematic content analysis of 105 qualitative transcripts pertaining to social capital was undertaken for this study Analysis was guided by the discourse on Social Network Theory to facilitate a systematic exploration of social capital in relation to changes in group membership, alongside positive and negative changes in social support (emotional, instrumental/material, appraisal, information) and social influence (norms) (Berkman and Glass, 2001).

Further effects on bonding and bridging social capital were also assessed (Putnam, $2000,2004)$. The former pertained to the nature and strength of relationships within organizations, in this case IMAGE loan groups and centres. The latter captured connections between IMAGE participants and the wider community. 


\section{Results}

843 women were successfully interviewed at baseline with a response rate of $98 \%$. The mean age of respondents was 42 years. $43 \%$ of women were married and nearly $2 / 3$ had a primary school education or less. Respondents were generally long-term residents of the community who reside locally for more than 11 months of the year. Average household size was seven people and formal employment was uncommon. There were no differences between intervention and comparison groups.

Respondents reported membership of religious organizations as most common among 18 social group options in our assessment of social networks, particularly churches (81\%) and prayer groups (16\%). Burial society membership was widespread (78\%), with one third of respondents admitting to being involved in two or more. Savings groups (stokvels) were the next most common (18\%), followed by membership in political organizations (6\%).

\section{Quantitative effects on social capital}

Data on intervention effects were derived from 430 loan recipients and 430 matched controls. Two-year follow up rates were $90 \%$ in the intervention arm and $84 \%$ in the comparison arm. Analyses were conducted on an intention-to-treat basis, and drop-out rates were low at $8 \%$ per year.

Few baseline differences in social capital were observed. However, women enrolled in the intervention were more often members of social groups than women in the control 
group $(p=0.01)$. They were also more likely to believe that community members would support one another in working together towards common goals $(p=0.06)$.

Table 2 presents changes in social capital after two years of follow-up. After adjusting for baseline imbalances, estimates for all indicators of social capital changed in a positive direction with large effect estimates for most indicators.

Women in the intervention group were more likely to report higher levels of SSC based on increased participation in social groups, and higher levels of CSC reflected by higher levels of perceived community solidarity in a time of crisis and higher levels of collective action. Perceptions on whether community members would support one another in working towards common goals changed less.

\section{Qualitative effects on social capital}

\section{Changes in structural social capital}

A woman's choice to take part in the IMAGE program included a commitment to join a 'new' social network. In effect, the introduction of the IMAGE intervention changed the landscape of locally available social groups in a context where group membership was seen an important form of social insurance. The solidarity, trust, and in some cases economic benefits of participation in these provided security for poor households during crisis events.

"SEF [Small Enterprise Foundation] money is not enough to weather family crises. We do society - stokvels (rotating credit and savings groups) and other 
community help projects for these reasons. There are many societies that do different services. So it is important to join almost every one of them." (FGD)

Participation in other non-IMAGE related community groups was also explored. In some instances, participants said the additional responsibilities associated with the intervention were limiting as they became so busy with their businesses that they were unable to engage in 'regular' social functions or attend to family problems.

However, in most instances involvement in IMAGE served to enhance social network participation. In some cases, the financial benefits of IMAGE facilitated membership of other organizations that required payment of monthly fees (such as burial societies or stokvels). "[With the new money from SEF] I now have my choice of stokvels to join" (FGD).

For others, there was evidence of gradual improvements in self confidence and self esteem, which also encouraged women to increase the frequency and quality of participation in social networks.

"[If I had not gone through the training] I would talk to you facing down, avoiding any form of eye contact with you. I would be very scared to look at you or any other person I was not used to." (KI)

"We do mokgodishwano and stokvels (savings groups) more than before. I think it is because that I see my life differently. I am now more active than before SEF." $(\mathrm{FGD})$ 


\section{Changes in cognitive social capital}

This section considers dynamics within IMAGE loan groups and centres, and highlights the role of bonding social capital experienced through participation in the intervention.

\section{Social support}

As the poor have little material collateral, the group lending model works on the premise of shared solidarity to guarantee loan repayments. In nearly all cases, prior trust relationships were emphasized. Thus, women joining loan groups were generally familiar with each other as members of the same church, stokvel or burial society. A pervasive theme throughout the qualitative assessment was the fundamental role of trust and solidarity in shaping experience and success within the program.

"I am happy because to work as a group has been a good idea. They say kopano ke maatla - unity is strength and I tend to agree with it. I do not think we would have made it working as individuals." (FGD).

When noting the types of support provided, nearly all groups cited financial and business advice as important benefits of group membership. However, emotional support was also commonly identified, manifested through assistance between loan group members in dealing with family matters such as illness, problems with children, or abusive partners. One participant remarked "if one member has a problem, the sun will never go down without us knowing it" (FGD). 
Participants also noted a number of factors that had the potential to undermine this solidarity including loan repayment problems; a lack of attendance at fortnightly loan centre meetings; leadership problems, particularly if there was evidence of corrupt practice or financial mismanagement; and malicious gossip. These occurred among only a small number of groups and centres.

\section{Social influence}

Participants recognized that shared norms evolved within loan groups over the course of the intervention, shaped partly through witnessing the success (or failure) of other participants.

Having particularly strong or vocal leaders played an important role in the development of group identity. One member noted of her group leader: "let me tell you that since we joined MM we are living up to our group's name (Itumiseng, "those with pride"). We are doing well under the leadership of MM. We are completely different" (FGD). Several groups cited the importance of a strong centre chairperson as 'setting the tone' - "she should be exemplary" remarked one participant (KI).

While strong and visible leaders were identified an important source of social influence, the role of regular day-to-day interactions with other poor women who did not necessarily stand out from the group, seemed to be equally important to the response of IMAGE participants. 
"From rubbing shoulders with hard workers like LM and FM, I have learnt a lot. ...I have met a lot of different people. I have learnt how to bargain for a good price. I feel I am wiser." (FGD)

\section{Bridging social capital}

\section{Broadening horizons}

Over the course of the intervention, participants described a number of ways in which interactions between IMAGE participants and the wider community took place. For many women, establishing a small business provided an important first opportunity to expand their social horizons - to 'see outside worlds' and 'meet different people'.

"It is important because we see things we did not know, places we did not know. We learn more in seeing different places, like Durban [to purchase stock for a clothes re-selling business]. We now know what the sea looks like...places that we never knew we would reach."(FGD)

Household effects

Evidence from the qualitative data suggests that for many, the content of the training sessions was both challenging and influential. New insights and understandings were first and foremost shared with children and partners. Some noted that "Each time I attend the centre meeting my children will be patiently waiting for me for more news." (FGD) 
Furthermore, they noted that prior to the intervention, such openness was unusual.

"These things were secret (sepiri). I never used to talk to my daughter about using condoms or prevention. I am grateful of health talks because they have helped me. My children are listening to me. Such knowledge makes any parent to be brave in facing their children" (FGD).

\section{Collective action}

Bringing together the economic and social dimensions of the intervention was an attempt to foster synergy, providing participants with both the means (income/empowerment) and the knowledge to address priority concerns. Some participants chose to work as individuals or small groups to engage wider community structures. For others, loan centres were able to mobilize very effectively to address common problems. Examples of each will be presented below. The 'success' of these efforts was difficult to gauge, and the process of community mobilization was inevitably fluid, rarely straightforward and highly unpredictable. Notably, not all centres or individuals engaged in such activities and the qualitative data suggest that for many, it was sometimes easier to engage in the 'public domain' than take steps to engage the 'private domain' at home.

There were a number of strategies employed by IMAGE participants to disseminate new insights and perspectives. Most chose to work through existing social networks in their communities. In some instances, centres targeted their churches and burial societies for gender and HIVIAIDS awareness raising initiatives and reported back at loan centre meetings. In other cases, women were individually tasked with visiting local clinics, hospitals and police stations to find out what services were available for victims of 
domestic violence. Others approached soccer clubs or primary schools as entry points for engaging young people.

Perhaps the most common form of action taken by IMAGE participants was as mediators in local conflicts. Participants described being asked to intervene in relationships and family crises. Most often, this took the form of marriage or relationship counselling, although in some instances, the interventions made by participants were quite dramatic such as actively preventing two young girls from being raped by a family member in one case, and in another, acting to address a situation where an older woman was being raped by her grandson. One IMAGE participant brought a civic leader to a fellow villager's home to assist in resolving a situation of parental neglect and abuse of a six year old daughter.

"Some women of the community have come to us for help. Remember the time when some woman asked us to help her with alcoholic sister who used to leave her child everywhere when drunk? Do you remember what we did? This is what being SEF member means to me." (FGD)

Events in which an entire loan centre took part to address a common concern presented the most visible manifestations of bridging social capital. Some centres identified problems that were clearly linked to gender and HIV, while others chose to focus on broader issues such as water supply, or disputes between leadership structures in the village. The data also suggest that a pre-condition for wider collective action was a wellfunctioning microfinance program. Among centres struggling with loan repayment problems, leadership challenges or lack of trust between members, community mobilization activities were much more limited. 
There are numerous examples of collective action and 'bridging effects' between loan centres and the wider community. It is important to note that within the context of the IMAGE intervention, these efforts were driven by participants themselves and not by the training team. While not an exhaustive list, loan centres organized at least 40 village workshops, 16 meetings with leadership structures, five civic marches, two partnerships with local institutions, and formed two new village committees to address common concerns.

Specific examples include:

- Bringing a men's group from Johannesburg to conduct a workshop for men and boys in their rural community

- Forming relationships with a local home-based care group, where they worked together on referrals and exchanging information

- A civil protest at a local police station after a centre member was raped. The favourable and supportive response of the police resulted in the formation of a Village Rape Committee that brought loan centres together with representatives from the police, traditional leadership structures and teachers.

- After a meeting with a local chief to discuss community safety issues, a new community group called Women Against Crime was formed. This group identified alcohol as a key driver of violence and HIV, and succeeded in establishing an early curfew at local liquor store, and in stopping the sale of alcohol to minors.

- Two loan centres worked together to organize a civic protests in support of the 16 days of activism for no violence against women. 
- After many attempts to chart a conciliatory resolution with a local clinic around the quality of services, loan centres held a sit-in in the office of a local hospital manager. They received a sympathetic hearing, and the meeting resulted in the children of loan centre members becoming volunteers at their local clinics.

"Some community members used to think that they (the centre) were crazy when they started mobilising for the hospital issue. They used to think that the women would never succeed. Some even said that the police would shoot at the women if they do what they wanted to do. But now that things have changed for the better those people are also benefiting." (KI)

\section{Discussion}

This study suggests that an intervention combining group-based microfinance with gender and HIV training has the potential to catalyze positive shifts in multiple dimensions of social capital among participating households relative to a matched comparison group over a two year period. Effects on structural social capital were large, with evidence of expanded social group membership. In this area of rural South Africa, involvement in religious organizations, financial savings organizations, and political parties were the major social groupings identified. There were also large effects on cognitive social capital associated with participation in the IMAGE intervention, particularly solidarity and collective action.

We used a randomized, controlled design with multiple intervention and control communities to generate unbiased estimates of effect. This allowed us to account for any baseline differences, as well as the effect of secular change taking place during the 
study period. This represents a substantial advance over previous research on both social capital and microfinance where experimental evaluations have been virtually absent (Armendariz de Aghion \& Morduch, 2005; Macinko \& Starfield, 2001; Pronyk et al., 2007). As logistical and ethical challenges constrained our ability to simultaneously enroll large numbers of villages, our study is limited by wide confidence intervals unlikely to exclude unity for many indicators. Thus the interpretation of our findings is based on the size, consistency and congruency of changes in pre-defined study outcomes, alongside an extensive portfolio of qualitative research (Habicht et al., 1999).

While statistical measures assessed the presence or absence of changes in social capital, qualitative methods present a far more complex picture of diverse responses to the intervention. With respect to social networks, while there was some evidence that additional responsibilities associated with IMAGE impeded further group membership, more commonly the reverse was the case. The combination of microfinance and training generated additional financial resources for participants, while simultaneously enhancing self-confidence and self-esteem. The positive effects of the intervention on numerous dimensions of empowerment have been highlighted elsewhere (Kim et al., 2007). Taken together, this expansion of financial and social resources seemed to improve both the quantity of social network membership as well as the quality of participation in these groups.

Qualitative research also drew attention to the bonding and bridging dimensions of social capital. Trust relationships within loan groups were viewed as central to establishing successful businesses, a factor noted in previous research on social capital from the microfinance sector (Karlan, 2001). Loan groups and centres provided opportunities for the exchange of emotional and financial resources, allowed mentorship and role- 
modelling to take place, and generated a strong sense of group identity and common purpose among participants. Findings also depict how these processes could be easily undermined by poor financial performance and loan repayment problems, a lack of attendance at meetings, corruption, and malicious gossip within centres.

There was also evidence of bridging effects, where participants worked individually and collectively to define and address priority issues in the wider community. Women made changes close home, through engaging partners and children in sensitive discussions, and then began to be drawn in to mediate what were sometimes quite serious and challenging household crises among neighbours. Many participants also utilized existing social groups, such as churches and burial societies, as entry points for disseminating their new knowledge and perspectives gained from the training program within their villages. Finally, there were numerous instances where loan centres worked collectively to address priority concerns - establishing effective partnerships with village leadership structures, the police, the health sector and local NGOs. However, our data caution that the potential for such bridging opportunities are limited in the presence of a poorly functioning microfinance program - findings echoed from experience elsewhere (Barr, 1998; Huda et al., 2005).

This work represents one of the few longitudinal studies to provide encouraging evidence that social capital can be intentionally generated in relatively short programmatic time frames. This contrasts to Putnam's proposal that the accumulation of social capital takes place only very slowly (Putnam et al., 1993). In their review, Kawachi and Berkman note that we have a far better understanding of forces that undermine social capital, as opposed to examples of interventions that strengthen it (Kawachi \& Berkman, 2000). However, others suggest that social capital may not be quite so 
historically fixed, and that it might be possible to build up social capital within relatively short spans of time (Schneider et al., 1997). Furthermore, it has been suggested that social capital gains might be accelerated through creative institutional partnerships, and by working at many levels simultaneously (Evans, 1997). IMAGE brought together health and development components to an intervention which may have produced synergistic effects on the generation of social capital.

There has been debate as to whether social capital constitutes a positive social resource in settings where material deprivation is quite marked (UNESCO, 2002). Some put forth that the entire discourse risks overly romanticizing community life, drawing attention away from pressing debates on poverty and inequality (Muntaner et al., 2001; Navarro, 2004; Ziersch et al., 2005). This study supports previous experience from South Africa suggesting that in the absence of other forms of capital, social capital does have the potential to play a critical role in supporting livelihoods and generally buttressing social and economic vulnerabilities (Gilbert \& Walker, 2002). Our work also resonates with research from the development sector suggesting that communities endowed with rich and diverse social networks may be in a stronger position to confront poverty and vulnerability (Moser, 1996), share beneficial information (Jonathan Isham, 1999) and resolve disputes (Schafft \& Brown, 2000). Indeed, wide social networks have been deemed quite useful in catalyzing the success of development projects (J. Isham et al., 1995).

Applying the perspectives and lessons learned from this study within public health more broadly, the clearest role for social capital theory may be in the design and implementation of community interventions. These attempt to influence the risk of a disease in individuals by addressing the conditions that contribute to and sustain 
vulnerabilities at the population-level (Sorenson et al., 1998). The success of community interventions lies in their ability to engage and strengthen social capital. They are grounded in the notion that healthy behaviour is better shaped by influencing social norms and negotiating collective identities, rather than through providing individuals with factual information (Stockdale, 1995). Ideally, interventions are designed through community consultation and involvement, and their implementation capitalizes on existing social networks (Sorenson et al., 1998). Process is as important as outcome, and notions of 'community competence' (Israel et al., 1994) and 'community empowerment' (Wallerstein \& Bernstein, 1994) feature prominently.

Over the past two decades, trials have been conducted in schools, workplaces and entire communities to reduce the risk of a variety of conditions such as heart disease, cancer, substance abuse and HIV infection. Interventions have varied from intensive screening and risk-factor management, to awareness raising and social marketing, to policy-level interventions such as increasing taxation on cigarettes. Their effects on chronic disease in industrialized countries have thus far been mixed (Susser, 1995). However, a recent cluster randomized trial of a facilitated learning intervention with women's groups in Nepal demonstrated dramatic reductions in neonatal and maternal mortality (Manandhar et al., 2004). It is possible that in developing countries, where health challenges and the space to improve remain great, and where the reach of secular change to comparison communities may be slower, the design and testing of such interventions could hold much promise. We hope this work stimulates further research in this regards. 


\section{Conclusion}

There remains much to learn about interventions to strengthen social capital, the process of community mobilization, and techniques to foster sustainable community participation in health. In the IMAGE Study, a multi-level intervention that provided economic, social and educational inputs resulted in reductions in levels of violence. While the data presented here suggest changes in social capital were also evident, they may not explain the whole story. Further analysis of the relative contribution of the various inputs to observed health benefits is currently underway - in an attempt to 'unpack the black box' (Wight \& Obasi, 2003).

Nonetheless, we suggest that applying a social capital framework to address major public health challenges in Africa was important and useful. It allowed for a rigorous and theory-driven assessment of both process and outcomes, alongside a deeper understanding of how to work effectively in communities where new insights and opportunities to further gains in health and development are urgently required. 


\section{References}

Armendariz de Aghion, B., \& Morduch, J. (2005). The Economics of Microfinance. Cambridge, Massachusetts and London, England: Massachusetts Institute of Technology Press.

Barr, A. M. (1998). Enterprise performance and the functional diversity of social capital. WPS/98-1. Oxford: Centre for the Study of African Economies.

Berkman, L., \& Syme, S. L. (1979). Social networks, host resistance, and mortality: A 9yr follow-up study of Alameda County residents. American Journal of Epidemiology, 109, 186-204.

Bolin, K., Lindgren, B., Lindstrom, M., \& Nystedt, P. (2003). Investments in social capital - implications for the production of health. Social Science and Medicine, 56, 2379-2390.

Coleman, J. (1988). Social capital in the creation of human capital. American Journal of Sociology, 94 Suppl, s95-120.

Collinson, M. A., Tollman, S. M., Kahn, K., Clark, S. J., \& Garenne, M. (2005). Highly prevalent circular migration: households, mobility and economic status in rural South Africa. In E. Preston-Whyte (Ed.), African Migration in Comparative Perspective (p. in press). Johannesburg: Wits University Press.

De Silva, M. J., McKenzie, K., Harpham, T., \& Huttly, S. R. A. (2004). Social capital and mental illness: a systematic review. Journal of Epidemiology and Community Health, 59, 619-627.

Drukker, M., Buka, S. L., Kaplan, C., McKenzie, K., \& Van Os, J. (2005). Social capital and young adolescents' perceived health in different sociocultural settings. Social Science and Medicine, 61, 185-198.

Evans, P. (1997). State-Society Synergy: Government and Social Capital in Development. University of California International and Area studies digital collection. Berkley,, Univerisity of California, Berkley, 178-209.

Field, J. (2003). Social Capital. London: Routledge.

Freire, P. (1994). Pedagogy of the Oppressed. New York: Continuum.

Friedman, S. R., \& O'Reilly, K. R. (1997). Sociocultural interventions at the community level. AIDS, 11(suppl A), s201-s208.

Galea, S., Karpati, A., \& Kennedy, B. (2002). Social capital and violence in the United States, 1974-1993. Social Science and Medicine, 55, 1373-1383.

Gilbert, L., \& Walker, L. (2002). Treading the path of least resistance: HIVIAIDS and social inequalities - a South African case study. Social Science and Medicine, 54, 1093-1110.

Grootaert, C., Narayan, D., Jones, V. N., \& Woolcock, M. (2003). Integrated Questionnaire for the Measurement of Social Capital (SC-IQ). Washington: World Bank Social Capital Thematic Group.

Grosskurth, H., Mosha, F., Todd, J., \& al., e. (1995). Impact of improved treatment of sexually transmitted diseases on HIV infection in rural Tanzania: randomized control trial. Lancet, 346, 530-536.

Habicht, J. P., Victoria, C. G., \& Vaughn, J. P. (1999). Evaluation designs for adequacy, plausibility and probability of public health program performance and impact. International Journal of Epidemiology, 28, 10-18.

Hagan, J., Merkens, H., \& Boehnke, K. (1995). Delinquency and disdain: social capital and the control of right-wing extremism among east and west Berlin youth. American Journal of Sociology, 100, 1028-1052. 
Hanifan, L. (1916). The rural school community center. Annals of the American Academy of Political and Social Science, 67, 130-138.

Harpham, T., Grant, E., \& Thomas, E. (2002). Measuring social capital within health surveys: key issues. Health Policy and Planning, 17(1), 106-111.

Hawe, P., \& Shiell, A. (2000). Social capital and health promotion: a review. Social Science and Medicine, 51, 871-885.

Holtgrave, D. R., \& Crosby, R. A. (2003). Social capital, poverty, and income inequality as predictors of gonorrhoea, syphilis, chlamydia and AIDS case rates in the United States. Sexually Transmitted Infections, 79, 62-64.

Huda, K., Rahman, S., \& Guirguis, C. (2005). Building social capital for the ultra poor: challenges and achievements. CFPR-TUP Working Paper Series No. 6. Dhaka and Ottawa: BRAC and Aga Khan Foundation Canada.

Isham, J. (1999). The effect of social capital on technology adoption: evidence from rural Tanzania. New York: American Economic Association annual meeting.

Isham, J., Narayan, D., \& Pritchett, L. (1995). Does participation improve performance? Establishing causality with subjective data. World Bank Economic Review, 11(2), 175-200.

Israel, B., Checkoway, B., Schultz, A., \& Zimmerman, M. (1994). Health education and community empowerment: Conceptualising and measuring perceptions of individual, organisational, and community control. Health Education Quarterly, 21, 149-170.

Karlan, D. (2001). Social Capital and Group Banking. Boston: Department of Economics, Massachusetts Institute of Technology.

Kawachi, I., \& Berkman, L. (2000). Social cohesion, social capital and health. In I. Kawachi \& L. Berkman (Eds.), Social Epidemiology pp. 174-190). New York: Oxford University Press.

Kawachi, I., Kennedy, B. P., Lochner, K., \& Prothrow-Stith, D. (1997). Social capital, income inequality, and mortality. American Journal of Public Health, 87(9), 14911498.

Kim, J. C., Watts, C. H., Hargreaves, J. R., Morison, L. A., Porter, J. D. H., Phetla, G., et al. (2007). Understanding the impact of a microfinance-based intervention on women's empowerment and the reduction of intimate partner violence in the IMAGE Study, South Africa. American Journal of Public Health, in press.

Knack, S., \& Keefer, P. (1997). Does social capital have an economic payoff? A cross country investigation. Quarterly Journal of Economics, 112, 1251-1288.

Krishna, A., \& Shrader, E. (1999). Social Capital Assessment Tool. pp. 1-16). Washington DC: World Bank.

Lundborg, P. (2005). Social capital and substance abuse among Swedish adolescents an explorative study. Social Science and Medicine, 61, 1151-1158.

Macinko, J., \& Starfield, B. (2001). The utility of social capital in research on health determinants. Milbank Quarterly, 79(3), 387-428.

Maluccio, J., Haddad, L., \& May, J. (2001). Social capital and household welfare. Journal of Development Studies, 36(6), 54-81.

Manandhar, D. S., Osrin, D., Shrestha, B. P., Mesko, N., J., M., Tumbahangphe, K. M., et al. (2004). Effect of a participatory intervention with women's groups on birth outcomes in Nepal: cluster-randomised controlled trial. The Lancet, 364, 970979.

Miller, D. L., Scheffler, R., \& al, e. (2006). Social capital and health in Indonesia. World Development, 34(6), 1084-1098.

Moser, C. (1996). Confronting crisis: a comparative study of household responses to poverty and vulnerability in four poor urban communities. Environmentally 
Sustainable Development Studies and Monographs Series 8. Washington, D.C: World Bank.

Muntaner, C., Lynch, J. W., \& al, e. (2001). Social capital, disorganized communities, and the third way: understanding the retreat from structural inequalities in epidemiology and public health. International Journal of Health Services, 31(2), 213-237.

Narayan, D., \& Pritchett, L. (1997). Cents and Sociability: household income and social capital in rural Tanzania. pp. 1-41). Washington: World Bank Policy Research Working Paper.

Navarro, V. (2004). Commentary: Is capital the solution or the problem? International Journal of Epidemiology, 33(4), 672-674.

Pronyk, P. M., Hargreaves, J. R., Kim, J. C., Morison, L. A., Phetla, G., Watts, C., et al. (2006). Effect of a structural intervention for the prevention of intimate partner violence and HIV in rural South Africa: a cluster randomized trial. The Lancet, 368, 1973-1983.

Pronyk, P. M., Hargreaves, J. R., \& Morduch, J. (2007). Microfinance programs and better health: prospects for sub-Saharan Africa. Journal of the American Medical Association (in press).

Putnam, R. (2000). Bowling Alone: the collapse and revival of the American community. New York: Simon and Schuster.

Putnam, R. (2004). Commentary: 'Health by association': some comments. International Journal of Epidemiology, 33(4), 667-671.

Putnam, R., Leonardi, R., \& Nanetti, R. (1993). Making Democracy Work: Civic Traditions in Modern Italy. Princeton, NJ: Princeton University Press.

RADAR. (2002a). Social Interventions for HIVIAIDS: Intervention with Microfinance for AIDS and Gender Equity. IMAGE Study Evaluation Monograph No. 1. Rural AIDS and Development Action Research Programme, School of Public Health, University of the Witwatersrand. http://web.wits.ac.za/NR/rdonlyres/BB91DCF74FDB-4F88-8CF0-9720DF6FB830/0/Monograph.pdf.

RADAR. (2002b). Social Interventions for HIVIAIDS: Intervention with Microfinance for AIDS and Gender Equity. IMAGE Study Intervention Monograph No. 2. Rural AIDS and Development Action Research Programme, School of Public Health, University of the Witwatersrand.

http://web.wits.ac.za/NR/rdonlyres/3C2A3B30-DE20-40E08A0AA14C98D0AB38/0/Intervention monograph picspdf.pdf.

Rose, D., \& Charlton, K. E. (2003). Prevalence of household food poverty in South Africa: results from a large, nationally representative survey. Public Health Nutrition, 5(3), 383-389.

Schafft, K., \& Brown, D. (2000). Social capital and grassroots development: the case of Roma self-governance in Hungary. Social Problems, 47(2), 201-219.

Schneider, M., Teske, P., Marschall, M., Mintrom, M., \& Roch, C. (1997). Institutional arrangements and the creation of social capital: The effects of public school choice. American Political Science Review, 91(1), 82-93.

Sorenson, G., Emmons, K., Hunt, M. K., \& Johnston, D. (1998). Implications of the Results of Community Intervention Trials. Annual Review of Public Health, 19, 379-416.

Stockdale, J. (1995). The self and media messages: match or mismatch? In I. Markova \& R. Farr (Eds.), Representations of health, illness and handicap pp. 31-48). London: Harwood.

Susser, M. (1995). Editorial: The tribulations of trials: Intervention in communities. American Journal of Public Health, 85, 156-160. 
Szreter, S., \& Woolcock, M. (2004). Health by association? Social capital, social theory, and the political economy of public health. International Journal of Epidemiology, 33(4), 650-667.

Thomson, H., Hoskins, R., Petticrew, M., Ogilvie, D., Craig, N., \& Quinn, T. (2004). Evaluating the health effects of social interventions. British Medical Journal, 328, 282-285.

UNESCO. (2002). Social capital and poverty reduction: which role for civil society organizations and the state. Geneva: UNESCO.

Veenstra, G. (2000). Social capital, SES and health: An individual level analysis. Social Science and Medicine, 50, 619.

Veenstra, G. (2002). Social captial and health (plus wealth, income inequality and regional health governance). Social Science and Medicine, 54, 849-868.

Wallerstein, N., \& Bernstein, E. (1994). Introduction to community empowerment, participatory education, and health. Health Education Quarterly, 21, 141-148.

Weitzman, E. R., \& Chen, Y. (2005). Risk modifying effect of social capital on measured on heavy alcohol consumption, alcohol abuse, harms, and secondhand effects: national survey findings. Journal of Epidemiology and Community Health, 59, 303-309.

Wickrama, K. A. S., \& Mulford, C. L. (1996). Political democracy, economic development, disarticulation, and social well-being in developing countries. The Sociological Quarterly, 375-390.

Wight, D., \& Obasi, A. (2003). Unpacking the 'black box': the importance of process data to explain outcomes. In J. Stephenson, J. Imrie \& C. Bonell (Eds.), Effective Sexual Health Interventions: issues in experimental evaluation. Oxford: Oxford University Press.

Woolcock, M., \& Narayan, D. (2000). Social capital: implications for development theory, research, and policy. World Bank Research Observer, 15(2), 225-250.

Yunus, M. (1999). The Grameen Bank. Scientific American, 281(5), 114-119.

Ziersch, A. M., Baum, F. E., MacDougall, C., \& Putland, C. (2005). Neighbourhood life and social capital: the implications for health. Social Science and Medicine, 60, 71-86. 
Table 1: Outcome variables

\begin{tabular}{|c|c|}
\hline $\begin{array}{l}\text { Social Capital } \\
\text { Outcome }\end{array}$ & Question \\
\hline $\begin{array}{l}\text { Structural } \\
\text { Social network Score } \\
\text { (Score derived from } \\
\text { group member } x \\
\text { intensity multiplier) }\end{array}$ & $\begin{array}{l}\text { List of } 18 \text { potential community groups } \\
\text { Intensity of Membership: member (1), active member (2), group leader (3) }\end{array}$ \\
\hline \multirow{3}{*}{$\begin{array}{l}\text { Cognitive } \\
\text { Perceived } \\
\text { Reciprocity and } \\
\text { Community support } \\
\text { (Positive response: } \\
\text { yes to any or all) }\end{array}$} & $\begin{array}{l}\text { If a community project does not directly benefit your neighbor but has benefits for others in the village/neighborhood, do you } \\
\text { think your neighbor would contribute time for this project? Yes or no }\end{array}$ \\
\hline & $\begin{array}{l}\text { If a community project does not directly benefit your neighbor but has benefits for others in the village/neighborhood, would your } \\
\text { neighbor contribute money (say about 10R) for this project? Yes or no }\end{array}$ \\
\hline & $\begin{array}{l}\text { If there were a problem that affected the entire village/neighborhood, for instance lack of water or electricity or a major flood, } \\
\text { which scenario do you think would best describe who would work together to deal with the situation? } \\
\text { Yes if the entire village would work together to solve the problem }\end{array}$ \\
\hline \multirow{4}{*}{$\begin{array}{l}\text { Perceived } \\
\text { Solidarity in a } \\
\text { Crisis } \\
\text { (Positive response: } \\
\text { yes to any or all) }\end{array}$} & $\begin{array}{l}\text { If your house has been destroyed by fire who could you turn to for shelter for } 2 \text { weeks? Yes if you could turn to people you do not } \\
\text { know at all }\end{array}$ \\
\hline & $\begin{array}{l}\text { If your house has been destroyed by fire who could you turn to for (money) R50 (\$7US) to help you buy clothes after the fire? } \\
\text { Yes if you could turn to people you do not know at all }\end{array}$ \\
\hline & $\begin{array}{l}\text { How confident are you that you alone could raise enough money to feed your family for four weeks? - this could be for example } \\
\text { by working, selling things that you own, or by borrowing money (from people you know or from a bank or money lender? Yes if } \\
\text { very confident }\end{array}$ \\
\hline & $\begin{array}{l}\text { Would you say that your household's ability to survive this kind of crisis is better, the same or worse as it was } 2 \text { years ago? } \\
\text { Better or worse/same }\end{array}$ \\
\hline \multirow{2}{*}{$\begin{array}{l}\text { Collective action } \\
\text { (Positive response: } \\
\text { yes to one or both) }\end{array}$} & In the past 2 years, have you participated in a meeting, march, rally or gathering around HIVIAIDS awareness? Yes or no \\
\hline & Have you ever been involved in the organization of such a meeting or gathering? Yes or no \\
\hline
\end{tabular}


Table 2: Estimates of the IMAGE intervention effect on social capital

\begin{tabular}{|c|c|c|c|c|c|c|c|}
\hline & \multicolumn{3}{|c|}{ Baseline } & \multicolumn{4}{|c|}{ Follow Up } \\
\hline & $\mathbf{I}$ & $\mathbf{C}$ & p-value & 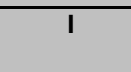 & C & $\begin{array}{c}\text { Unadjusted RR } \\
(95 \% \mathrm{Cl})\end{array}$ & $\begin{array}{c}\text { Adjusted RR* } \\
\text { (95\% Cl) }\end{array}$ \\
\hline & $\mathrm{n} / \mathrm{N}(\%)$ & $\mathrm{n} / \mathrm{N}(\%)$ & & $\mathrm{n} / \mathrm{N}(\%)$ & $\mathrm{n} / \mathrm{N}(\%)$ & & \\
\hline \multicolumn{8}{|l|}{ Structural Social Capital } \\
\hline More participation in social groups & $\begin{array}{c}112 / 422 \\
(26.6) \\
\end{array}$ & $\begin{array}{l}53 / 416 \\
(12.7) \\
\end{array}$ & 0.01 & $\begin{array}{c}275 / 386 \\
(71.2) \\
\end{array}$ & $\begin{array}{c}133 / 363 \\
(36.6) \\
\end{array}$ & $1.96(1.02-3.78)$ & $1.85(0.95-3.61)$ \\
\hline \multicolumn{8}{|l|}{ Cognitive Social Capital } \\
\hline $\begin{array}{l}\text { Belief in community support } \\
\text { towards common goals }\end{array}$ & $\begin{array}{l}242 / 426 \\
(56.8)\end{array}$ & $\begin{array}{l}171 / 419 \\
(40.8)\end{array}$ & 0.06 & $\begin{array}{l}232 / 387 \\
(60.0)\end{array}$ & $\begin{array}{l}184 / 362 \\
(50.8)\end{array}$ & $1.14(0.39-3.36)$ & $1.11(0.38-3.24)$ \\
\hline $\begin{array}{l}\text { Greater perception of community } \\
\text { solidarity in a time of crisis }\end{array}$ & $\begin{array}{l}300 / 419 \\
(71.6)\end{array}$ & $\begin{array}{l}264 / 414 \\
(63.8)\end{array}$ & 0.35 & $\begin{array}{l}306 / 387 \\
(79.1)\end{array}$ & $\begin{array}{l}179 / 363 \\
(49.3)\end{array}$ & $1.68(0.83-3.39)$ & $1.65(0.81-3.37)$ \\
\hline Taken part in collective action & $\begin{array}{l}167 / 407 \\
(41.0)\end{array}$ & $\begin{array}{l}146 / 403 \\
(36.2)\end{array}$ & 0.18 & $\begin{array}{l}290 / 383 \\
(75.7)\end{array}$ & $\begin{array}{l}124 / 361 \\
(34.4)\end{array}$ & $2.22(1.05-4.70)$ & $2.06(0.92-4.49)$ \\
\hline
\end{tabular}

*Adjusted RRs calculated on the basis of expected number of events from a logistic regression model on individual data with independent variables including age, village pair, marital status (Cohort 1 only), and baseline measure 